\section{Pacific Northwest}

National Laboratory

Operated by Battelle for the

U.S. Department of Energy

\title{
PNNL IR Sensing SHRIKE Tests
}

\author{
WW Harper \\ RM Williams \\ JD Strasburg \\ EC Golovich \\ JS Thompson \\ TL Stewart \\ BJ Tweedy
}

September 2005

Prepared for the U.S. Department of Energy under Contract DE-AC05-76RL01830

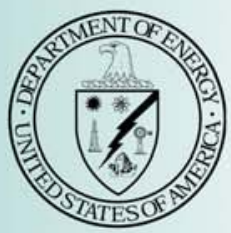




\title{
DISCLAIMER
}

This report was prepared as an account of work sponsored by an agency of the United States Government. Neither the United States Government nor any agency thereof, nor Battelle Memorial Institute, nor any of their employees, makes any warranty, express or implied, or assumes any legal liability or responsibility for the accuracy, completeness, or usefulness of any information, apparatus, product, or process disclosed, or represents that its use would not infringe privately owned rights. Reference herein to any specific commercial product, process, or service by trade name, trademark, manufacturer, or otherwise does not necessarily constitute or imply its endorsement, recommendation, or favoring by the United States Government or any agency thereof, or Battelle Memorial Institute. The views and opinions of authors expressed herein do not necessarily state or reflect those of the United States Government or any agency thereof.

\author{
PACIFIC NORTHWEST NATIONAL LABORATORY \\ operated by \\ BATTELLE \\ for the \\ UNITED STATES DEPARTMENT OF ENERGY \\ under Contract DE-AC05-76RL01830
}

Printed in the United States of America
Available to DOE and DOE contractors from the Office of Scientific and Technical Information,
P.O. Box 62, Oak Ridge, TN 37831-0062;
ph: (865) 576-8401
fax: $(865)$ 576-5728
email: reports@adonis.osti.gov

\begin{abstract}
Available to the public from the National Technical Information Service, U.S. Department of Commerce, 5285 Port Royal Rd., Springfield, VA 22161 ph: (800) 553-6847 fax: $(703) 605-6900$ email: orders@ntis.fedworld.gov online ordering: http://www.ntis.gov/ordering.htm
\end{abstract}

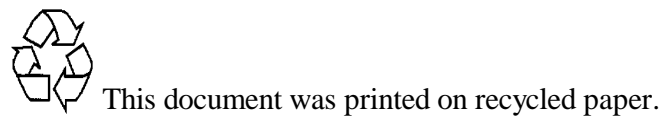


PNNL IR SENSING SHRIKE TESTS

Warren Harper, Richard Williams, Jana Strasburg, Elizabeth Golovich, Jason Thompson, Tim Stewart, Brianna Tweedy

\section{EXECUTIVE SUMMARY}

Pacific Northwest National Laboratory deployed two chemical sensors during the week of July $11^{\text {th }}, 2005$ as part of the NPTEC Shrike Tests. Both systems successfully detected ammonia during all four of the releases that took place on July $13^{\text {th }}$.

\section{EXPERIMENTAL SETUP}

PNNL deployed two chemical sensors during the week of July $11^{\text {th }}, 2005$ as part of the NPTEC Shrike tests. Both systems were optimized to detect ammonia. The Short-Wave Infrared Cavity Ringdown Spectrometer (SWIR-CRDS) is a pointsensor (i.e. "sniffer") based on cavity-enhanced optical absorption spectroscopy operating near 1.53 microns. The SWIR-CRDS was positioned approximately 63 meters downwind from the ammonia release point. A trailer-based remote sensor based on a frequency modulated differential absorption lidar (FM-DIAL) technique was located at Trailer Park \#1 and used a 9.55 micron quantum cascade laser beam to interrogate the plume. A retro-reflector target was deployed $1.82 \mathrm{~km}$ from the trailer with the line-of-sight intersecting the 225 line approximately $270 \mathrm{~m}$ downwind of the release point. A schematic of the experimental layout is shown at

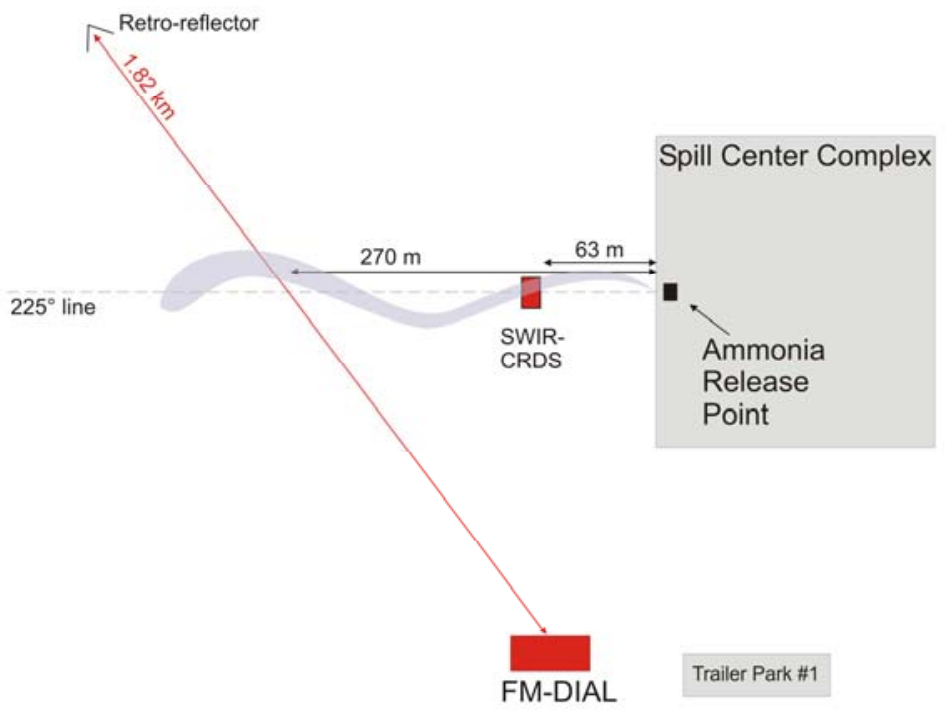
right.

\section{Short-Wave Infrared Cavity Ringdown Spectrometer}

In the SWIR-CRDS, air is continuously draw into the instrument through a 1/4" inlet and analyzed in near real time to yield an absolute ammonia concentration at a data rate of approximately one concentration value per second (this is a unique quality of the PNNL instrument compared to other sniffer type instruments). Based on tests performed in the laboratory prior to deployment at NTS the lower detection limit for the instrument is approximately $400 \mathrm{ppb}_{\vee}$ ammonia in a 350 Torr sample.

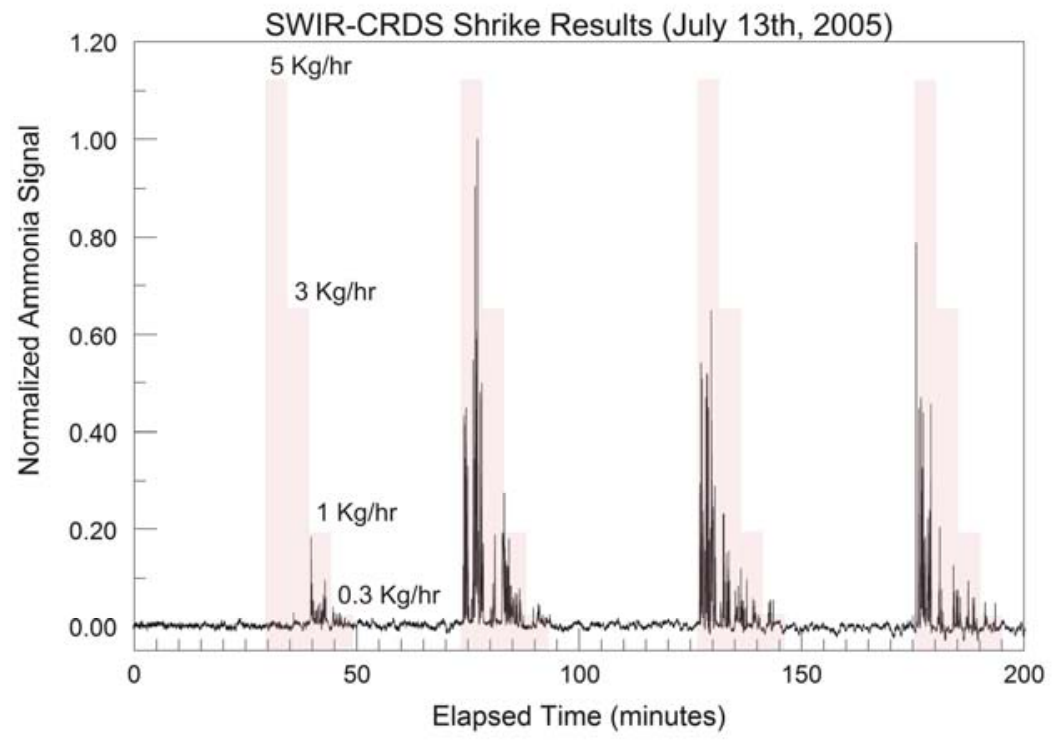

The SWIR-CRDS has been reduced in size and is now enclosed in a 44" $\times 23$ " $\times 26$ " $(\mathrm{L} \times$ $\mathrm{W} \times \mathrm{D}$ ) transportable crate. For convenience at the test site, the instrument was mounted on a 4-wheel mobile cart which also supported a small air conditioner used to maintain acceptable internal operating temperatures during the $105-110^{\circ} \mathrm{F}$ afternoons at NTS. The SWIR-CRDS instrument was transported to NTS inside the FM-DIAL trailer. Once unloaded at the Spill Center the system was powered up and began recording data within 30 minutes. A portable weather station was used to log wind speed and direction at the sensor. Control of the autonomous instrument was maintained via a wireless link to a laptop computer 750 meters away at Trailer-Park $\# 1$, without the need to make manual handson adjustments. Starting Monday July $11^{\text {th }}$ 
the instrument ran continuously through the afternoon of Thursday July $14^{\text {th }}$ with the only exception occurring one evening when the computer unexpectedly malfunctioned. Only one planned ammonia release sequence occurred during the week (during the afternoon of July $13^{\text {th }}$ ). During a sequence, ammonia was released consecutively at 4 decreasing rates $(5,3,1$ and $0.3 \mathrm{Kg} / \mathrm{hr}$ ) each lasting 5 minutes (this cycle was repeated a total of four times on the $13^{\text {th }}$ ). The figure above depicts the resulting data obtained from the instrument during the ammonia release (due to classification restrictions related to the FM-DIAL results, the actual ammonia signal levels observed at the SWIRCRDS instrument are left in arbitrary units). For most of the first sequence the wind blew the ammonia in a direction away from the instrument (hence no signal). Because the ammonia plume is physically narrow, even at 63 meters, small changes in wind direction result in large swings in the observed ammonia levels. These rapid swings in signal amplitudes, due to plume dynamics, are easily seen in the data as a result of the one second response time of the SWIR-CRDS instrument.

\section{FREQUENCY-MOdULATEd DifFERENTIAL ABSORPTION LIDAR TRAILER}

The FM-DIAL trailer was deployed on Monday July 11 and collected data from Monday afternoon through the afternoon of July $14^{\text {th }}$. In the experimental setup, the FM-DIAL laser beam is approximately 1 meter in diameter as it passes the 225 line. Assuming the plume is 1 meter in diameter 270 meters downwind of the release point, the maximum volume the FM-DIAL system is interrogating is approximately 1 cubic meter. The integrated pathlength concentration detected by the FMDIAL system is affected both by inhomogeneities in the plume as well as vertical motion of the plume relative to the laser beam. These two
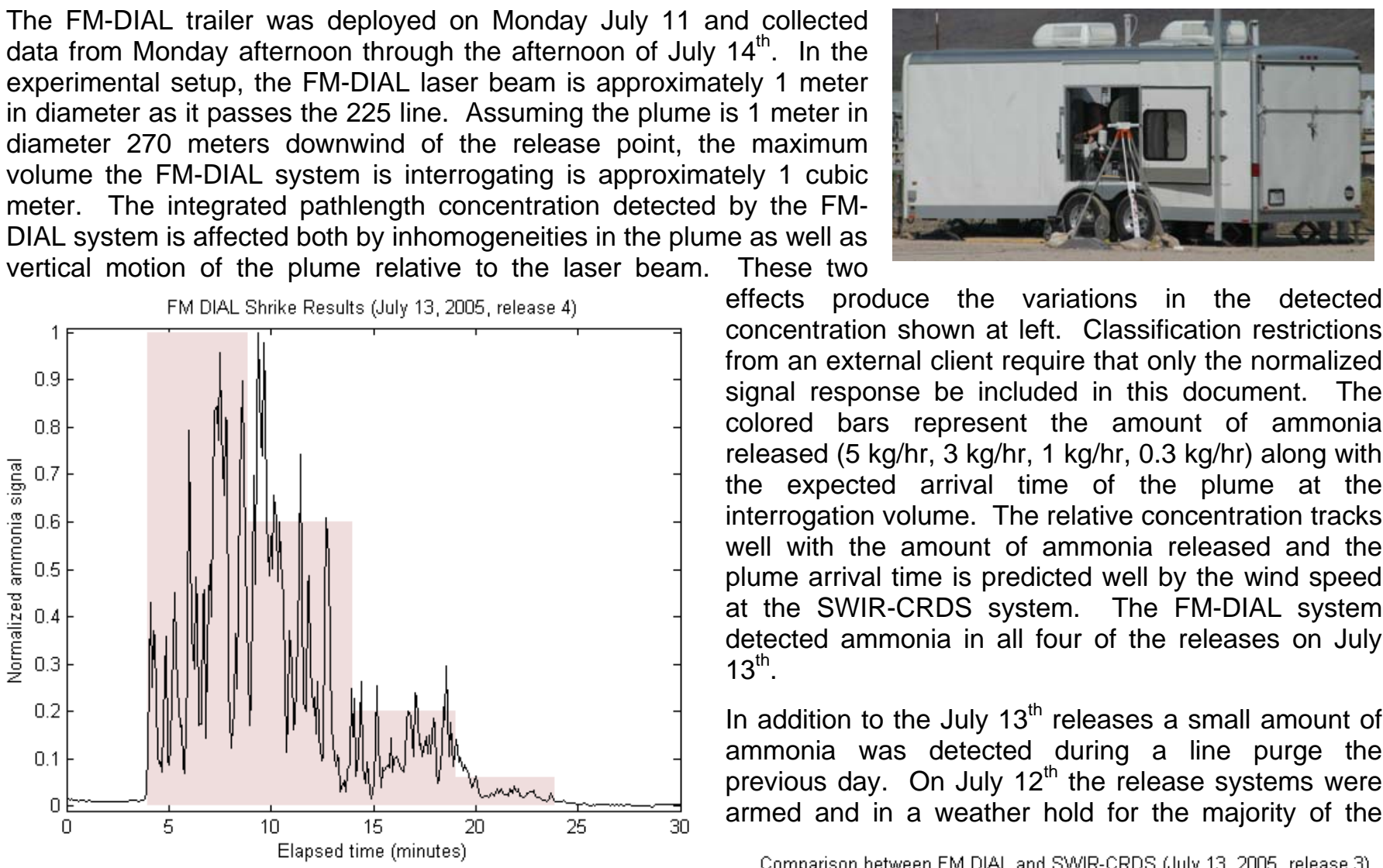

effects produce the variations in the detected concentration shown at left. Classification restrictions from an external client require that only the normalized signal response be included in this document. The colored bars represent the amount of ammonia released ( $5 \mathrm{~kg} / \mathrm{hr}, 3 \mathrm{~kg} / \mathrm{hr}, 1 \mathrm{~kg} / \mathrm{hr}, 0.3 \mathrm{~kg} / \mathrm{hr}$ ) along with the expected arrival time of the plume at the interrogation volume. The relative concentration tracks well with the amount of ammonia released and the plume arrival time is predicted well by the wind speed at the SWIR-CRDS system. The FM-DIAL system detected ammonia in all four of the releases on July $13^{\text {th }}$.

In addition to the July $13^{\text {th }}$ releases a small amount of ammonia was detected during a line purge the previous day. On July $12^{\text {th }}$ the release systems were armed and in a weather hold for the majority of the

afternoon, but conditions were never favorable enough for a release. During the arming process a 6 foot length of $3 / 8$ " tubing was filled with ammonia. Once the release was canceled, the tube was purged. The NPTEC team provided a countdown for this purge and the FM DIAL system successfully detected a puff of gas lasting only 2.5 seconds.

\section{SENSOR CoMPaRISON}

Comparison between the SWIR-CRDS and FM-DIAL data yields insight into the plume dynamics during the third release. The results are shown at right. The two sensors were separated by a little more than 200 meters. In addition the SWIR-CRDS system only sampled air through a 1/4" inlet while the FM-DIAL system interrogated roughly 1 cubic meter of air. Despite these differences, the comparisons of the two signals show striking similarities.

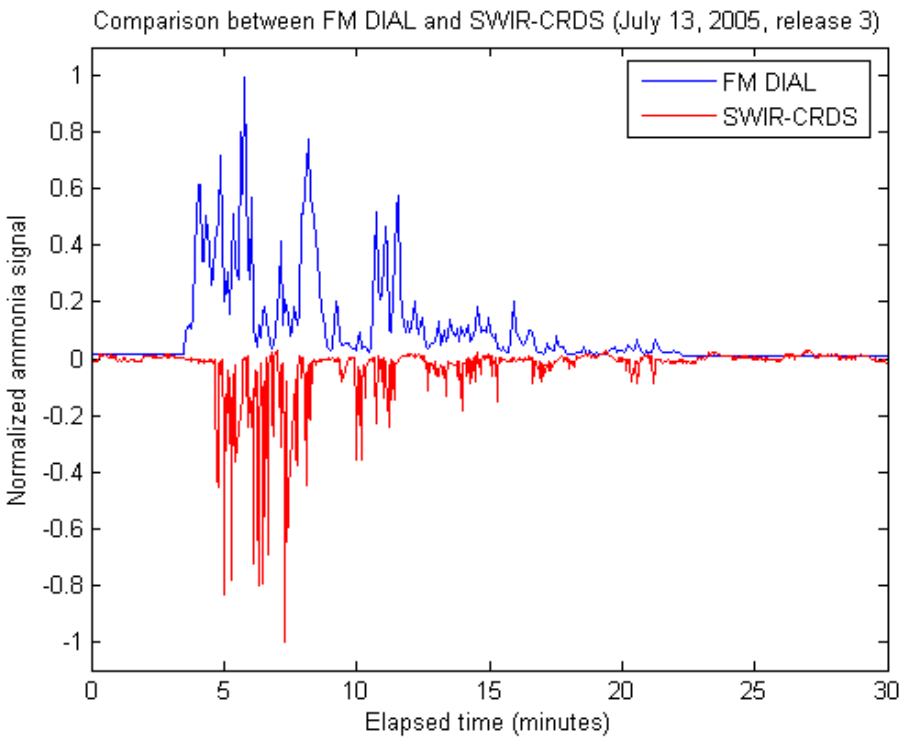

